\title{
TINJAUAN SISTEM DESAIN PEMANFAATAN AIR HUJAN PADA RUMAH TINGGAL DI BINTARO, JAKARTA
}

\author{
Renhata Katili \\ Architecture Department, Faculty of Engineering, Binus University \\ Jl. K.H. Syahdan No. 9, Palmerah, Jakarta Barat 11480 \\ renhatakatili@yahoo.com
}

\begin{abstract}
Rainwater harvesting and collecting for household domestic needs is someting commonly found. Even in some countries in Africa and Asia, it has been known for a long time. Currently, the technology varies from the simple one like using a barrel up to the purification technology. Unfortunately the rainwater harvesting system commonly found now is rarely integrated as a planned building element. Indeed, the integration will bring good impact on both design and function. This article analyzes a two-story residential building that uses Rainwater harvesting and collecting system which is located in Bintaro, Jakarta, as one example of a planned architecture that uses the system.
\end{abstract}

Keywords: rainwater collecting, rainwater harvesting, building element, residential

\begin{abstract}
ABSTRAK
Menangkap dan menampung air hujan untuk memenuhi kebutuhan domestik rumah tangga bukan hal yang baru. Bahkan di beberapa negara di Afrika dan Asia, cara dan teknologi ini sudah dikenal sejak lama. Saat ini, mulai dari teknologi sederhana seperti menampungnya dalam tong bekas hingga penggunaan teknologi pemurnian air hujan mudah ditemui. Sayangnya penampungan air hujan yang ada saat ini jarang terintegrasi sebagai elemen bangunan yang terencana. Padahal integrasi desain ini akan berdampak baik secara fungsi dan juga secara desain. Artikel ini menganalisis sebuah bangunan rumah tinggal dua lantai yang menggunakan sistem penangkapan dan penampungan air hujan di kawasan Bintaro, Jakarta, sebagai salah satu contoh bentuk arsitektur bangunan yang telah direncanakan sejak awal untuk menggunakan sistem tersebut.
\end{abstract}

Kata kunci: penangkapan air hujan, penampungan air hujan, elemen bangunan, rumah tinggal 


\section{PENDAHULUAN}

Letak geografis Indonesia menyebabkan negara tropis ini hanya memiliki dua musim, penghujan dan kemarau. Di saat musim penghujan, beberapa kota di pulau Jawa sering terjadi banjir. Sebaliknya pada musim kemarau, kota-kota ini juga mengalami kekeringan yang berkepanjangan. Di saat inilah terasa pentingnya untuk menampung limpahan air hujan untuk menjaga pasokan akan kebutuhan air rumah tangga.

Selain faktor musim, ada beberapa alasan mengapa penting untuk memanfaatkan air hujan ini untuk kebutuhan domestik, yaitu: meningkatnya kebutuhan akan air, terbatasnya pasokan air, kualitas air tanah yang menurun di beberapa kota besar, dan sumber air bersih sangat jauh untuk dijangkau di beberapa daerah.

Pemanfaatan air hujan ini telah banyak dilakukan dari generasi terdahulu, biasanya untuk kebutuhan pertanian atau peternakan. Namun kini banyak juga telah digunakan untuk memenuhi kebutuhan rumah tangga. Berikut beberapa keuntungan dari pemanfaatan air hujan, yaitu: konstruksi yang sederhana, perawatan yang mudah, kualitas air yang cukup baik, dampak lingkungan yang minim.

Pemanfaatan air hujan dalam arti luas dapat didefinisikan sebagai kumpulan limpasan air hujan untuk persediaan air rumah tangga, pertanian dan pengelolaan lingkungan. Sistem pemanenan air hujan ini terdapat dua cara, yaitu ditampung dari limpasan atap dan ditampung di permukaan tanah. Analisis dalam tulisan ini berfokus pada pemanenan air hujan dari permukaan atap di tingkat rumah tangga untuk keperluan rumah tangga itu sendiri (Gambar 1).

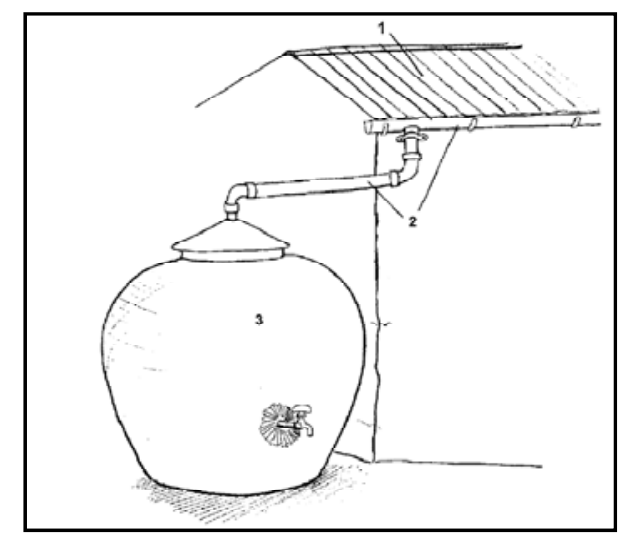

Gambar 1. Sistem pemanenan air hujan ( Sumber: Rainwater Harvesting Implementation Network (RAIN)

\section{METODE}

Metode yang digunakan dalam pembahasan ini adalah pengamatan langsung lapangan dan juga studi literatur. Pengamatan dikhususkan pada upaya desain yang optimal yang dapat diaplikasikan pada bangunan rumah tinggal. 


\section{HASIL DAN PEMBAHASAN}

\section{Tipe Pengumpulan Air Hujan}

Tipe yang digunakan untuk mengumpulkan air hujan pada bangunan rumah tinggal 2 lantai di Bintaro, Jakarta ini adalah menggunakan atap miring (Gambar 2). Menurut Skinner (2004), beberapa material atap memiliki perbedaan karakteristik dan koefisien aliran air, seperti bahan tanah liat yang menyerap air lebih banyak dibanding keramik atau bahan lembaran lain.

Keuntungan dari penggunaan atap sebagai pengumpul air hujan adalah air yang terkumpul akan lebih sedikit terkontaminasi karena posisinya berada diatas bangunan. Selain itu, tidak membutuhkan biaya tambahan untuk menangkap air hujan karena atap itu sendiri sudah pasti tersedia di setiap rumah.

Namun ada beberapa kekurangan tipe pengumpulan air hujan dengan menggunakan atap, yaitu ukurannya yang terbatas. Dan akan sangat mahal apabila atap ini dibuat ekstra sendiri untuk menangkap air hujan (tidak ada dalam eksisting).

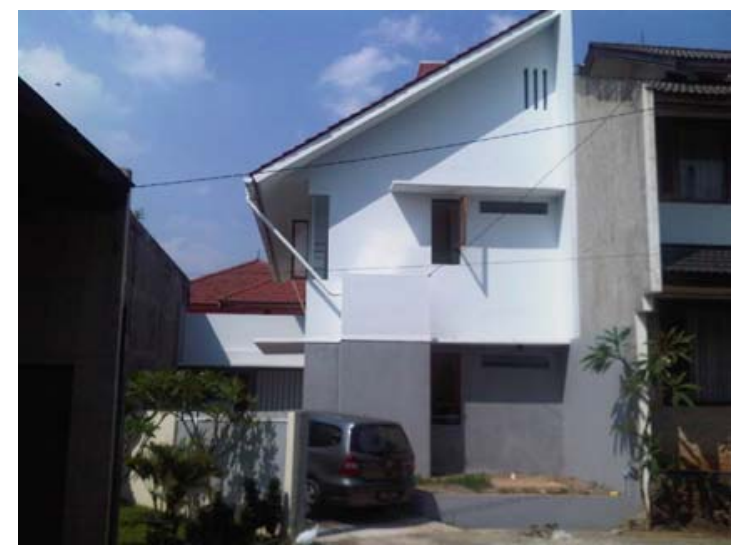

Gambar 2. Rumah tinggal yang menggunakan sistem pemanfaatan air hujan (Sumber: pribadi).

Berikut adalah skema sistem pemanfaatan air hujan yang didesain oleh penulis (Gambar 3).

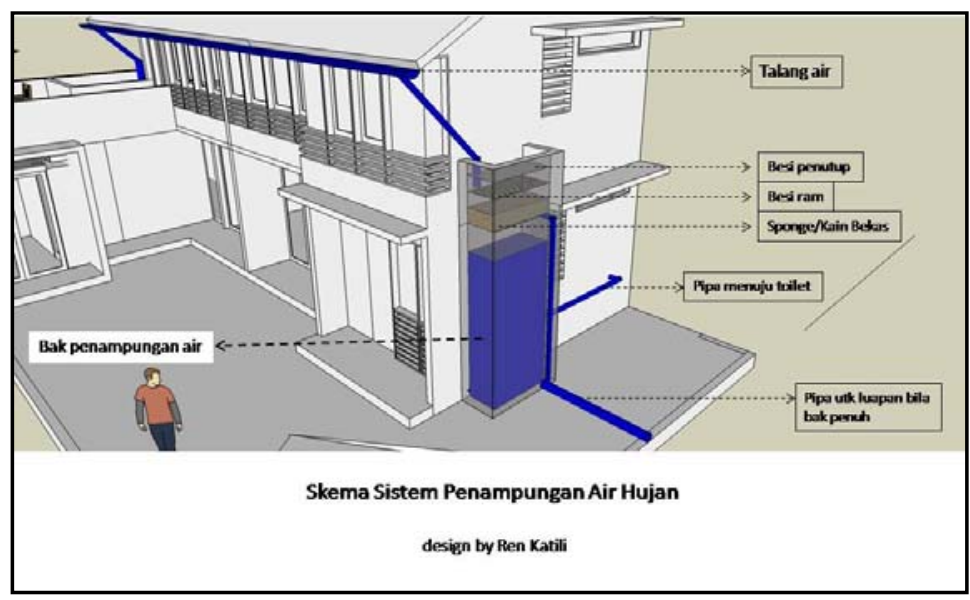

Gambar 3. Skema sistem pemanfaatan air hujan (Sumber: pribadi). 


\section{Kalkulasi Perhitungan Sistem Pengumpulan Air Hujan}

Menurut skinner (p. 3.18., 2004) ada tiga hal penting di dalam perencanaan pemanfaatan air hujan, yaitu: kuantitas air yang dibutuhkan dan waktu dibutuhkannya, jumlah air yang hilang dari sistem, dan pola hujan.

\section{Kuantitas kebutuhan air}

Kebutuhan air untuk kebutuhan rumah tangga dapat mencakup air minum, mencuci bahan makanan, masak, mandi, mencuci dan membersihkan rumah. Dalam tambahannya, Skinner (2004) mencatat jumlah air yang dapat dipenuhi dari sebuah skema air hujan seringkali terbatas karena kurangnya ukuran atap dan volume tangki penyimpanan. Jumlah air hujan yang seharusnya dapat dikumpulkan dan ditampung tidak dapat terpenuhi secara cukup selama musim kemarau.

Dalam kasus ini, luas atap rumah tinggal obyek penelitian ini $+/-50 \mathrm{~m}^{2}$ dengan volume tanki penyimpanan sebanyak 2000 liter. Jumlah ini hanya mampu untuk memenuhi kebutuhan penyiraman WC dan kebun.

\section{Hilangnya air dari sistem}

Menurut Skinner (2004), air yang ditangkap dapat hilang di tiga titik, yaitu area penangkapan air (atap), area pengaliran air kedalam penyimpanan (talang), dan area penyimpanan (tanki)

Volume Air hujan yang dapat ditangkap selama musim penghujan dapat dihitung menggunakan rumus:

$$
\mathrm{V}=\mathrm{C} \times \mathrm{A} \times \mathrm{d}
$$

di mana $V$ adalah volume dalam liter, $A$ adalah luas area penangkapan dalam hal ini adalah luas atap, $d$ adalah curah hujan selama periode berlangsung dalam $\mathrm{mm}$, dan $C$ adalah koefisien dari runoff.

Selanjutnya, Skinnermembahkan bahwa jika atap talang terlalu kecil untuk membawa aliran pada saat puncak hujan deras, intens mereka akan meluap. Jika talang tersebut tidak dibangun dengan baik, akan bocor setiap kali hujan. Kedua situasi tersebut mengurangi jumlah penyimpanan air yang masuk sehingga upaya harus dilakukan untuk mengurangi kerugian sekecil mungkin.

\section{Pola Hujan}

Untuk mencari volume minimum penyimpanan yang diperlukan oleh sistem pengumpulan air hujan kita perlu mengetahui kebutuhan sistem, kerugian dari sistem dan pasokan air dari curah hujan (Skinner, 2004). Catatan curah hujan selama periode mungkin diperlukan untuk merancang suatu sistem pengumpulan air hujan dengan baik.

\section{SIMPULAN}

Pemanfaatan air hujan ini telah banyak dilakukan dari generasi terdahulu, biasanya untuk kebutuhan pertanian atau peternakan. Namun kini banyak juga telah digunakan untuk memenuhi kebutuhan rumah tangga. Ada beberapa alasan memanfaatkan air hujan untuk kebutuhan domestik, yaitu: meningkatnya kebutuhan akan air, terbatasnya pasokan air, kualitas air tanah yang menurun di beberapa kota besar, dan sumber air bersih sangat jauh untuk dijangkau di beberapa daerah. 
Beberapa keuntungan dari pemanfaatan air hujan, yaitu: konstruksi yang sederhana, perawatan yang mudah, kualitas air yang cukup baik, dampak lingkungan yang minim. Dalam kasus ini, kurang luasnya tempat penangkapan dan penampungan air hujan mengakibatkan minimnya volume air hujan yang dapat ditampung. Satu satunya cara untuk dapat dilakukan adalah dengan menambah jumlah tangki penyimpanan sehingga dapat memasok kebutuhan air untuk kebutuhan domestik rumah tangga.

\section{DAFTAR PUSTAKA}

Harvey, P. (2005). Water Source Development. Unpublished lecture note, WEDC, Loughborough University, United Kingdom.

Skinner, B. (2004). Small Scale Water Supply and Sanitation. Postgraduate Module, WEDC, Loughborough University, United Kingdom.

The World Bank. (1990). Water and Sanitation Publications. Washington, D.C.: Water and Sanitation Division, Infrastructure and Urban Development Department (Policy, Planning, and Research Staff), The World Bank. 